\title{
A Note on Methods for Vertical Accuracy Assessment of DEMs
}

\author{
Nota sobre los Métodos de Evaluación de la Precisión Vertical de los DEM \\ Nota sobre Métodos para a Avaliação da Precisão Vertical dos DEMs \\ Marvin E. Quesada ${ }^{1}$ \\ Matthew Marsik ${ }^{2}$
}

Recebido em 28/09/2015. Aceito em 07/02/2017.

\begin{abstract}
This study investigates the vertical accuracy of a DEMs interpolated from 1:50,000 contours with universal kriging (UK) using DEMs interpolated from 1:10,000 contours as the independent source of higher accuracy following the geospatial accuracy standards proposed by the Federal Geographic Data Committee, FGDC, (1998). In accordance with the standards, the 1:10,000 contours do not qualify as well-defined points with known horizontal position and a high degree of accuracy that are easily visible and recoverable on the ground. Hence, DEMs are created from the 1:10,000 contours and used to check the vertical accuracy of the 1:50,000 DEMs with elevation errors, an RMSE and vertical accuracy measure calculated between the 1:10,000 and 1:50,000 DEMs. Other methods of vertical accuracy assessment for the 1:50,000 DEMs include a comparison of elevation ranges, visualization of error surfaces and latitudinal and longitudinal terrain profiles.
\end{abstract}

Key Words: DEMs. Interpolation. Topography. Geospatial accuracy. Vertical accuracy. Costa Rica.

RESUMEN: Este estudio investiga la exactitud vertical de un modelo de elevación digital interpolado desde una escala 1:50,000, usando MED interpolado de 1:10,000 con líneas de contorno como una fuente independiente de alta precisión y siguiendo los indicadores propuestos por la Federal Geographic Data Committee, FGDC, (1998). De acuerdo con esos indicadores los contornos de una escala 1: 10000 no califican como puntos bien definidos en una posición horizontal conocida y un alto nivel de precisión, los cuales pueden ser fácilmente visibles y recolectados en el campo. Por ello, los MEDs son creados a partir de contornos a escala 10000 y usados para corroborar la precisión vertical a una escala 150000. Además, los MEDs incluyen una comparación de los rangos de elevación, visualizan errores en la superficie y los perfiles latitudinales y longitudinales.

Palabras Clave: MEDs. Interpolación. Topografía. Precisión geoespacial. Precisión vertical. Costa Rica.

RESUMO: Este estudo investiga a precisão vertical de um modelo de elevação digital interpolado a partir de uma escala de 1:50.000, utilizando MED pontilhadas de 1:10000 com linhas de contorno como uma fonte independente de alta precisão e seguindo os propostos pelos indicadores do Comitê Federal de Dados Geográficos, CFDC (1998). De acordo com estes indicadores, os contornos de uma escala de 1:10.000 não são qualificadas como pontos bem definidos em uma posição horizontal conhecido e um alto nível de precisão, o que pode ser facilmente visto e recolhido no campo. Portanto, MEDs são criados a partir de escala 10.000 contornos e, utilizados para corroborar a precisão vertical numa escala 1:50000. Além disso, as MEDs incluem uma comparação de gamas de elevação, erros de superfície de exibição e perfis latitude e longitude.

Palavras-chave: MEDs. Interpolação. Topografia. Exatidão geoespacial. Precisão vertical. Costa Rica.

Geografia (Londrina) v. 26. nº. 2. p. 5 -22, jul/dez, 2017.

ISSN 2447-1747 


\section{INTRODUCTION}

A digital elevation model (DEM) is a computer-based, abstraction of elevation representing terrain that is infinitely complex and continuous in extent. Digital elevation is a mathematically continuous surface that attempts to represent closely the true nature of the actual terrain (CARTER, 1988). Three classic forms of DEMs are contour lines of a fixed interval, a raster-based, matrix structure with a fixed cell size, and a mesh of points connected by triangular facets (Triangular Irregular Network). Since real world terrain is infinitely complex and varied, DEMs are simplified models without the micro topography of the surface of the Earth. Hence, DEMs are prone to errors, albeit gross, systematic and/or random in nature. Since DEMs have a wide range of applications, the error detection is important to the accuracy of the modeling process and results to simulate, essentially, the physical process being modeled.

Uses of DEMs include hydrologic modeling, sediment transport modeling, floodplain delineation, point-source pollution modeling, terrain modeling and analysis, site selection and suitability analysis. Moore et al. (1991) provide an early review of the characteristics, limitations, and applications of digital elevation data to many modeling applications with a primary focus on hydrologic applications. Florinsky (1998b) offers an in depth review of digital terrain and elevation models detailing combined applications with remotely sensed data in vegetative, geochemical, soil-based, geological, climatological, glaciological and hazard studies. Wechsler (2007) provides a review of uncertainty and errors in DEMs focused on interpolation methods, scale, and derived terrain products in hydrologic modeling. Accuracy and reliability of environmental modeling results depend on error inherent in DEMs from the original elevation data and creation process, especially those created from contour lines (FISHER AND TATE, 2006; ROBINSON, 1994; CARTER, 1988). Often, policy decisions potentially affecting many people depend on the accuracy of these results, therefore DEMs should be as error free as possible.

Contours are readily available source of elevation data, especially in developing countries like Costa Rica, and are easily created using photogrammetry from aerial photographs or digitizing from topographic maps of various scales. Many previous studies used commercially available DEMs from the agencies like the USGS (GAO, 1995, KYRIAKIDIS ET AL., 1999; HOLMES ET AL., 2000; KENWARD ET AL., 2000) or those derived from remotely sensed imagery (BOLSTAD AND STOWE, 1994; KENWARD ET AL., 2000; THOMPSON ET AL., 2001), both of which are not readily available at high spatial resolutions (e.g. less than 30 meters) for developing, tropical countries due to production cost or often not usable due to thick

Geografia (Londrina) v. 26. nº. 2. p. 5-22, jul/dez, 2017. 
cloud cover. Field surveyed elevation using GPS or traditional surveying techniques (EDM or theodolite, Desmet 1997) are expensive to collect and rugged terrain and dense forest cover prevents accessibility to important topographic features, such as hilltops, ridges, and valleys. Wilson (2012) offers a state-of-art review on the use of LiDAR and RADAR remote sensing technologies to capture terrain, natural and anthropogenic features and the processes used to create derived data products and quantify error and propagation of uncertainty.

The use of higher horizontal and vertical accuracy DEMs for vertical accuracy assessment of smaller scale DEMs offers an inexpensive alternative to costly GPS derived points (BOLSTAD AND STOWE, 1994; KYRIAKIDIS ET AL, 1999; HOLMES ET AL. 2000). None of the domestic studies using elevation checkpoints for vertical accuracy assessment published after 1998 (HOLMES ET AL., 2000; KENWARD ET AL., 2000) acknowledge or follow closely FGDC accuracy standards.

In this study, we use universal kriging interpolation (MCBRATNEY AND WEBSTER, 1986) to create eight digital elevation models from $1: 50,000$ scale contours of a small area in Costa Rica, and test their vertical accuracy using DEMs interpolated from 1:10,000 scale contours. We map the spatial distribution of errors between the two datasets, and visualize changes and systematic errors in topography using elevation profiles.

\section{Methods}

The modeled geographical area is located in the central valley of Costa Rica (Figure 1) with rugged and varied topography due to accumulation of volcanically derived, pyroclastic flows with fluvially dominated erosion as the primary controls of landscape creation. The terrain is undulating in nature with a NE-SW trending ridge in the southwest corner and an N-S ridge along the eastern edge with the Río Grande de San Ramón river valley to the west of the N-S ridge. In the northwest corner, the Quebrada Bolivar river valley is the primary topographic feature. The city of San Ramón occupies the central gently sloping area between the ridges and Rio Grande valley; this area was formed by deposition of lake sediments.

Kriging is a statistical based interpolator that models a direction dependent spatial trend, distance dependent local spatial autocorrelation between data points, and random stochastic variation at observed points (MCBRATNEY AND WEBSTER, 1986; BOLSTAD, 2002). Data estimation at unmeasured points is made using statistically chosen weights, optimized to minimize prediction errors, based on existing data points. A variogram models distance dependent autocorrelation accounted for by the semi variance between pairs of observed data points. Data pairs are grouped by lag distance values, which are the distance between points, 
into bins, creating the empirical semivariogram, which has a nugget value $\left(C_{O}\right)$ denoting the initial semivariance of the data when autocorrelation is high, a sill $(C)$ that is the semivariance with little autocorrelation between points, and the range (a), which is the lag distance when the sill is reached. Empirically derived semivariograms are matched to theoretical variograms that are mathematically derived (MCBRATNEY AND WEBSTER, 1986; BOLSTAD, 2002).

Figure 1. Location of study area.

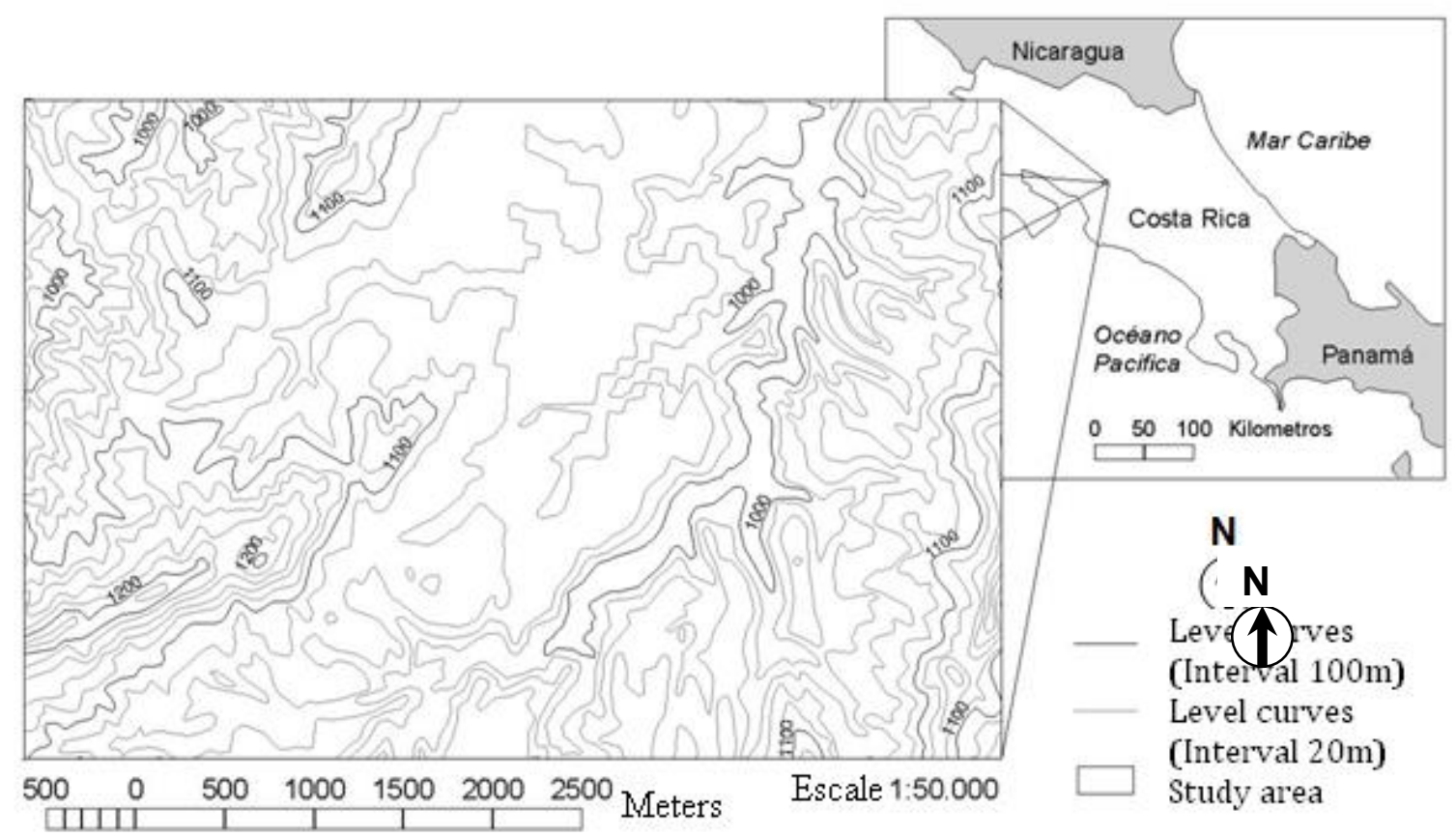

Source: author.

As implemented in ArcGIS Geostatistical Analyst, the universal kriging (UK) equation is as follows

$$
Z(s)=\mu+\varepsilon(s)
$$

where $Z(s)$ is the unknown point value, $\mu$ is the population mean and $\varepsilon(s)$ is the random error term or data variance (JOHNSTON ET AL., 2004). As employed here, UK assumes an unknown mean and incorporates an underlying polynomial trend in the data (JOHNSTON ET AL., 2004) that allows to vary smoothly both locally and globally in the dataset (LO AND YEUNG, 2002). The trend is deterministic by nature and can be subtracted from the data whereby the remaining autocorrelation is modeled from the random errors (CHANG, 2002).

Geografia (Londrina) v. 26. nº. 2. p. 5 - 22, jul/dez, 2017. 
Kriging calculates the statistically most probable surface based on the empirical variogram. McBratney and Webster (1986) explain more common forms of the theoretical semivariogram models including the spherical and exponential theoretical models used in our study. The semivariogram models provided in ArcGIS Geostatistical Analyst are bounded models with a defined sill. The spherical semivariogram model was chosen due to its application for terrain modeling and in geological surveys (MOORE ET AL., 2001). The spherical model is derived using the geometric equation resulting from the volumetric overlap of two spheres and is used for representing variance in three-dimensional bodies such as sedimentary structures and ore bodies (Moore et al, 2001). The mathematical equations of the spherical model are given as:

$$
\begin{array}{ll}
\gamma(h)=C_{0}+C\left(1.5 h / a-0.5 h^{3} / a^{3}\right) & 0<h<=a \\
\gamma(h)=C+C_{0} & h>a \\
\gamma(0)=0 &
\end{array}
$$

The exponential model is computed using varying randomly sized geometric figures and is given by the following equations:

$$
\begin{array}{ll}
\gamma(h)=C_{0}+C\left(1-e^{(-h / r)}\right) & 0<h \\
\gamma(0) & =0
\end{array}
$$

Equations 2 and 5 represents the range of both models, bounded between the nugget, $\gamma(0)$ and $a$, the range. The nugget can be also represented by $C_{0}$, with $h$ as the semivariance value, and the sill as $C$. Equation 3 represents the sill of the spherical model and the nugget is shown by equations 4 and 6 for the spherical and exponential models, respectively.

ESRI ArcGIS was used to preprocess the contour data and create the kriging surfaces. Number Crunching Statistical Software (NCSS) was used to test data normality and statistical significance of variance testing between the 1:10,000 and 1:50,000 DEMs.

The 1:10,000 and 1:50,000 contour data used to create the DEMs were derived from the topographic map sheet San Ramón, HOJA 3346III (IGN 1991), and Naranjo, HOJA 3346 (IGN, 1982) furnished by the Instituto Geográfico Naciónal, San José, Costa Rica. The 1:10,000 contours lines were created, from aerial photography flown in 1989, using stereophotogrammetric methods and have a primary interval of 5 meters, with an auxiliary interval of 2.5 meters; the elevation ranges from 965 meters to 1232.5 meters. The 1:50,000 contours lines were created from stereophotogrammetric methods in 1981 using aerial

Geografia (Londrina) v. 26. nº. 2. p. 5 - 22, jul/dez, 2017. 
photography flown in 1979 and 1980 and have an interval of 20 meters with an elevation range from 960 meters to 1220 meters.

Data pre-processing involved converting the contour line data from AutoCAD DXF format to ArcGIS coverage format, matching the spatial extent of the $1: 50,000$ and $1: 10,000$ contours using a clipping process in ArcGIS and converting from contour lines to elevation points for interpolation. Using ArcGIS Geostatistical Analyst data exploration tools, the points were investigated for global trends to determine the type of kriging interpolation and to model the mean trend of the data.

The grid resolution was determined by calculating the area of the smallest topographic feature in the 1:10,000 data, a hilltop, and four grid cells were chosen to represent the shape of a square, a $2 \times 2$ matrix of cells. Dividing the shortest length of this $2 \times 2$ matrix in half, 10 meters, gave a cell size of 5 meters. Another method of determining the appropriate cell size is by applying the Nyquist frequency, which states two samples are needed to capture the frequency of an object (NYQUIST, 1928). The identified hilltop has an area of 48.5 square meters; if two cells are used to represent the hill, each with an area of 24.25 square meters, calculating the square root yields a side dimension of 4.92 meters or approximately 5 meters.

The RMSE of the 1:50,000 DEMs are calculated using the 1:10,000 DEMs as the "truth" elevation surface. The 1:50,000 DEMs are the test surfaces. The residual errors between the $1: 10,000$ and 1:50,000 DEMs are calculated and maps of spatial distributions of the errors produced. One inherent requirement for a meaningful calculation of RMSE is the elevation errors are random, normally distributed, and have a mean value of zero (DESMET, 1997). The global RMSE from the checkpoints is defined as:

$$
\operatorname{RMSE}_{\mathrm{Z}}=\left[\left(\Sigma\left(\mathrm{Z}_{\mathrm{PT}}-\mathrm{Z}_{\mathrm{DEM}}\right)^{2} / \mathrm{n}-1\right)\right]^{1 / 2}
$$

where $Z_{P T}$ is the checkpoint elevation, $Z_{D E M}$ is the DEM elevation at the checkpoint and $n$ is the number of checkpoints. Random samples of 950 points were chosen from each 1:50,000 error surfaces for Kolmogorov-Smirnov normality testing. Upon failing to reject the normality test, the vertical accuracy, Accuracy $y_{2}$, defined as the linear error reported at the 95\% confidence level (GREENWALT AND SCHULTZ, 1968 as cited in FEDERAL GEOGRAPHIC DATA COMMITTEE, 1998), for each 1:50,000 DEM can be computed for the $1: 50,000$ DEMs using the following equation:

$$
\operatorname{Accuracy}_{z}=1.96 * \mathrm{RMSE}_{z}
$$

Geografia (Londrina) v. 26. nº. 2. p. 5-22, jul/dez, 2017. 
Confidence intervals at the $95 \%$ confidence level were then constructed about the mean elevation error to discern if the value of zero lies within these intervals indicating a mean elevation error of zero.

Latitudinal and longitudinal elevation transects were created across both the 1:10,000 and 1:50,000 DEMs. Elevation transects consist of lines of points across the DEMs with each point co-located to the center of DEM cell the transect passes over to ensure the elevation value for each DEM cell is transferred to each point in the transect. A custom script was written to assign point data values from the interpolated rasters. These transect were visualized to identify systematic shifts between the 1:10,000 and 1:50,000 DEMs.

Figure 2. Global trends in the elevation data

(a) Second order

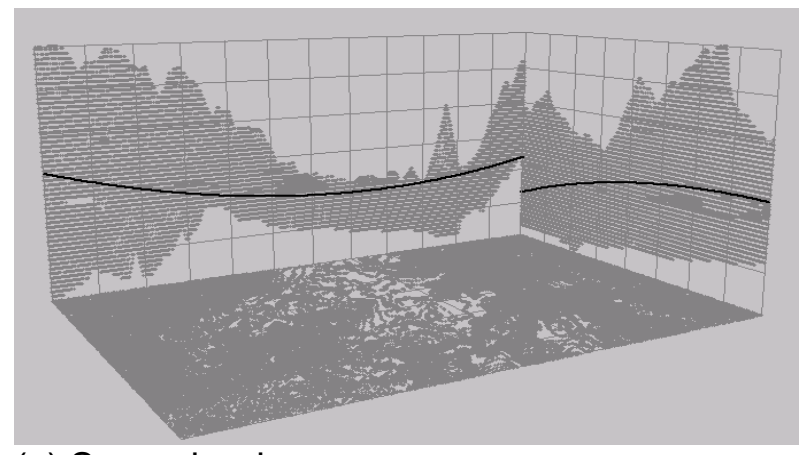

(c) Second order

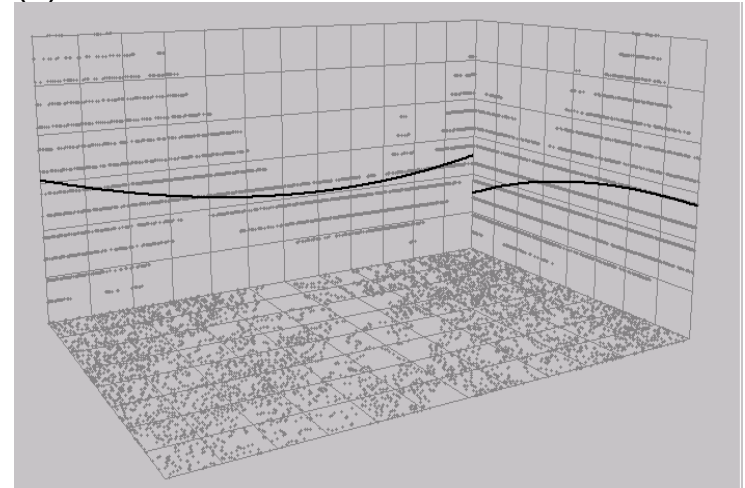

(b) Third order

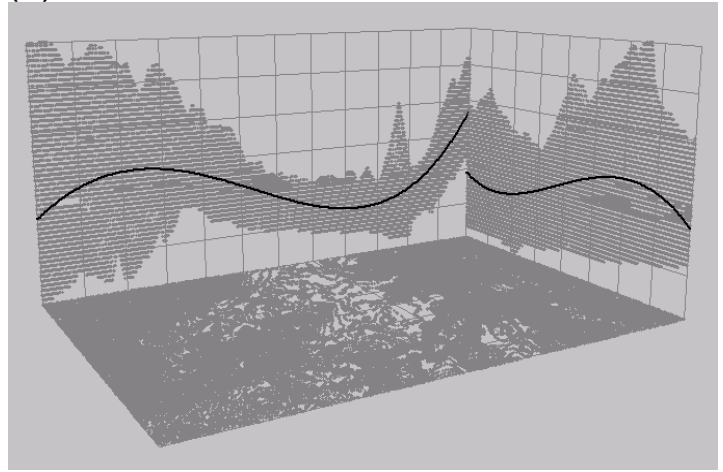

(d) Third order

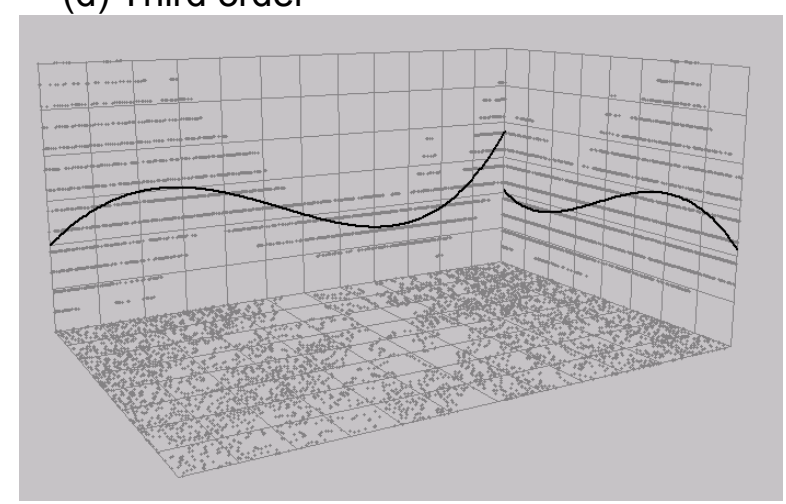

Contour scales: 1:10,000, (a) and (b), and 1:50,000 (c) and (d).

Source: author.

\section{Results}

Exploratory data analysis of the elevation point data used to generate the DEMs indicated the presence of global trends. From Figure 2, second and third order trends appear to 
fit the elevation points, therefore both were chosen to model the global mean of the data in the UK interpolations. Table 1 shows the UK model parameters used in the interpolation. The same UK parameters were used in interpolating the $1: 10,000$ and $1: 50,000$ DEMs from their respective contours.

The a range of values for the range, nugget and sill of the semivariogram resulted from varying the lag size and the number of lags, which place data points into similar groupings based on semivariance values and distance between points. Both the spherical and exponential theoretical semivariograms models were used since they are derived using three-dimensional geometric objects which represent well terrain (MCBRATNEY AND WEBSTER, 1986), inherently a three dimensional surface. In general, the spherical model produces smaller range and sill values than the exponential model with the exception of UK5, which has an equal range to UK1 and a larger sill. With respect to trend order, the primary difference indicated range and sill values were lower for the third order models than the second order models regardless of semivariogram model chosen.

Table 1. Universal kriging parameters for both 1:10,000 and 1:50,000 DEMs

\begin{tabular}{llllllll}
\multicolumn{9}{c}{ SemivariogramTrend } & $\begin{array}{l}\text { Lag } \\
\text { Model }\end{array}$ & $\begin{array}{c}\text { Range } \\
\text { Model }\end{array}$ & Order LagsizeNumber(a) & $\begin{array}{l}\text { Nugget } \\
\text { (Co) }\end{array}$ & $\begin{array}{l}\text { Sill } \\
\text { (Co + C) }\end{array}$ \\
\hline UK1 & Exponential & 2nd & 110 & 10 & 1092 & 0 & 1394.6 \\
UK2 & Exponential & 2nd & 110 & 30 & 2358 & 0 & 2120.7 \\
UK3 & Exponential & 3rd & 110 & 10 & 1092 & 0 & 924.31 \\
UK4 & Exponential & 3rd & 110 & 30 & 802.1 & 0 & 800.88 \\
UK5 & Spherical & 2nd & 110 & 10 & 1092 & 0 & 1487.3 \\
UK6 & Spherical & 2nd & 110 & 30 & 1675 & 38.379 & 1990.979 \\
UK7 & Spherical & 3rd & 110 & 10 & 774 & 22.317 & 849.747 \\
UK8 & Spherical & 3rd & 110 & 30 & 699 & 14.076 & 796.076
\end{tabular}

The first method for evaluating the error between the 1:10,000 and 1:50,000 DEMs examined the elevation ranges of the interpolated DEMs. Figure 3 shows the ranges for the 1:10,000 DEMs have nearly identical minimum and maximum values regardless of the semivariogram used, the trend modeled, and the range, nugget and sill parameters specified. The UK interpolation did not extrapolate the minimum and maximum elevation values much beyond that of the original 1:10,000 contour data, 965 to 1232.5 meters. In contrast, for the 1:50,000 DEMs, the selection of interpolation parameters affect the resulting elevation range.

Geografia (Londrina) v. 26. nº. 2. p. 5 -22, jul/dez, 2017. 
For those DEMs created with the third order trend, the maximum elevation is about 90 meters larger than the maximum elevation value of the original 1:50,000 contours.

Figure 3. UK DEM elevation ranges

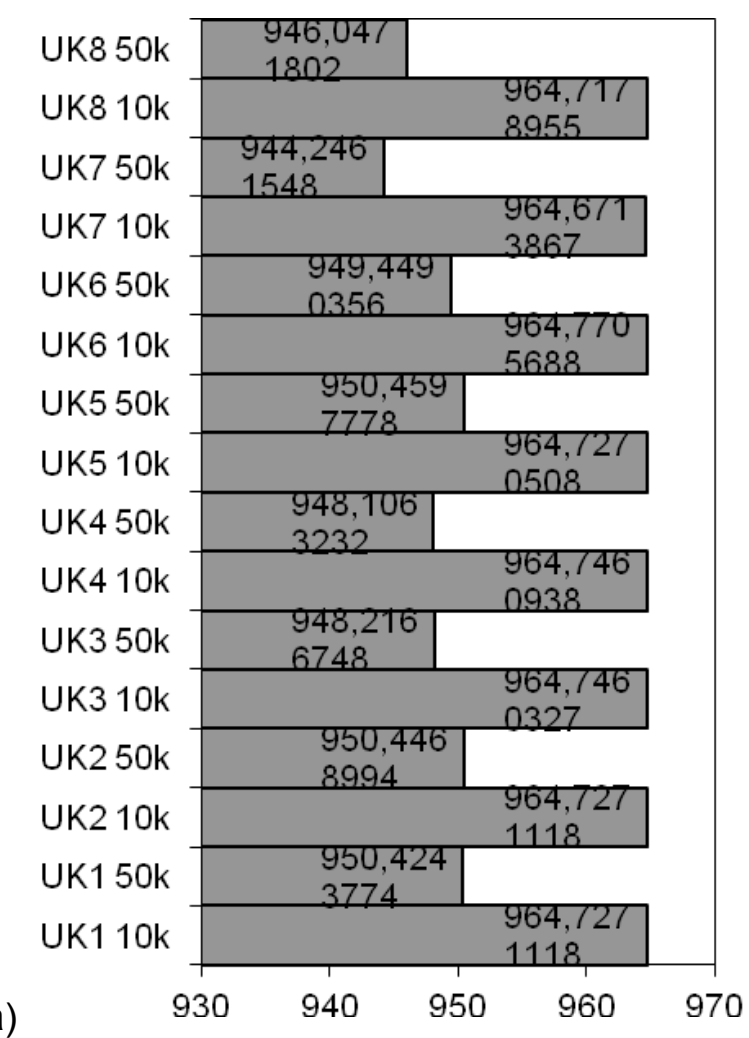

Minimum (a) and maximum (b)

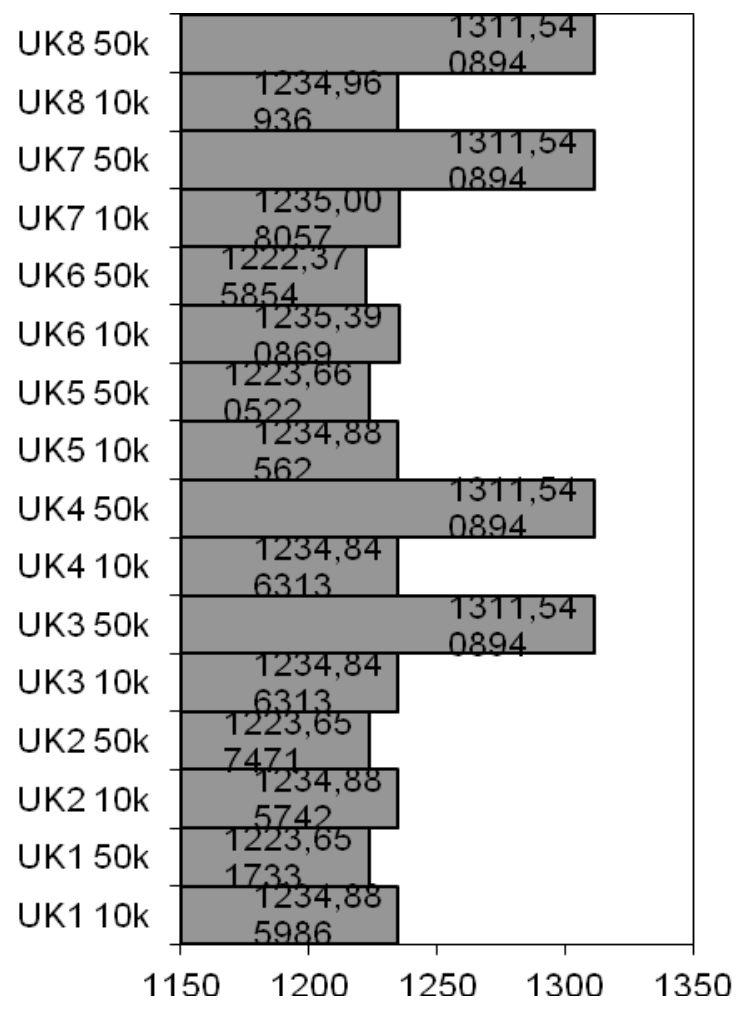

Source: author.

The minimum elevation value for the DEMs created with third order trend is lower (about 2 to 6 meters) than those 1:50,000 DEMs created with a second order trend. These observations of elevation minimums and maximums occurred regardless of the semivariogram model used. That is, the choice of global trend was the dominant control over the resultant range of elevations. For the 1:50,000 DEMs using a second order trend, there is a slight extrapolation beyond the original 1:50,000 contour elevation range, 960 to 1220 meters.

In conjunction with the elevation ranges reported above, Table 2 gives elevation errors, RMSE and the Accuracyz calculated between the 1:10,000 and 1:50,000 DEMs. The Kolmogorov-Smirnov normality test for the random sample of elevation errors $(n=950)$ produced test value from 0.014 to 0.035 with a critical value of 0.035 at $95 \%$ confidence. The elevation errors follow a normal distribution since the test values are less than the critical value. The lower and upper confidence intervals (LCL@95\% and UCL@95\%) indicated the mean 
elevation value could not equal zero at $95 \%$ confidence. A negative elevation error denotes areas where the 1:50,000 DEMs overpredict the elevation respective to the 1:10,000 DEMs and the opposite holds for positive elevation errors, where the 1:50,000 DEMs underpredict elevation. Similar to the descriptive statistics, the order of the global trend dominates the error values.

Table 2. Elevation errors between 1:10,000 and 1:50,000 DEMs

\begin{tabular}{lllllllll} 
Model & RMSE AccuracyZ & ErrorMin & ErrorMax & ErrorMean & ErrorStdev & LCL@95\% & UCL@95\% \\
\hline UK1 & 8.161 & 15.996 & -34.577 & 42.045 & 4.181 & 7.016 & 4.165 & 4.196 \\
UK2 & 8.159 & 15.992 & -34.576 & 42.018 & 4.181 & 7.014 & 4.165 & 4.196 \\
UK3 & 8.343 & 16.352 & -246.690 & 59.788 & 4.212 & 7.232 & 4.196 & 4.228 \\
UK4 & 8.344 & 16.354 & -246.690 & 59.782 & 4.212 & 7.234 & 4.196 & 4.227 \\
UK5 & 8.159 & 15.992 & -34.575 & 42.002 & 4.181 & 7.013 & 4.165 & 4.196 \\
UK6 & 8.119 & 15.913 & -34.675 & 44.356 & 4.164 & 6.977 & 4.149 & 4.179 \\
UK7 & 8.361 & 16.388 & -246.692 & 61.593 & 4.196 & 7.263 & 4.180 & 4.212 \\
UK8 & 8.35 & 16.366 & -246.692 & 60.932 & 4.202 & 7.246 & 4.186 & 4.217 \\
Source: author.
\end{tabular}

The 1:50,000 DEMs created with second order trends have similar error ranges regardless of semivariogram models used. DEMs modeled with third order trends show very large negative errors, possibly indicating gross errors, with the maximum error, albeit larger by about 18 meters, close to DEMs with the second order trends. The mean and standard deviation of errors and the RMSE for all 1:50,000 DEMs were similar in magnitude as the third order DEMs and slightly larger than the second order DEMs. The Accuracyz was computed and the overall vertical accuracy can be declared for the 1:50,000 DEMs as "Tested 15.996, 15.992, $16.352,16.354,15.992,15.913,16.388,16.366$ meters vertical accuracy at $95 \%$ confidence level" per Federal Geographic Data Committee (1998). Given similarities in value, these statistics do not provide a good indicator as to which 1:50,000 DEMs are better and the slight variation in values was due to random blunder errors resulting from the interpolation process.

Spatial distributions of elevation errors can indicate locations where the interpolation performed well or poorly. Figure 4 is representative of the error distributions between the 1:10,000 and 1:50,000 DEMs regardless of interpolation method. The trend order again differentiates the types of interpolation errors present in the DEMs. For those DEMs with second order trends, the large negative errors were found within valleys, topographic depressions, and areas with low relief, such as the city of San Ramón (Figure 4b). High positive errors were generally found in areas of topographic highs, ridges and hilltops. The errors found in Figure $4 b$

Geografia (Londrina) v. 26. n. 2. p. 5 -22, jul/dez, 2017. 
were to be expected and resulted in the different contour interval used in interpolating the 1:10,000 and 1:50,000 DEMs.

The 1:10,000 contours have a smaller interval and thus preserve better the micro topography of the topographic highs and lows. The aforementioned errors were present in the DEMs with a third order trend, but large errors were visible possibly resulting from the global trend order and the interpolation method. The areas located in Figure $4 a, 4 e$, and $4 \mathrm{f}$ may result from interpolation problems near the edge of the contours caused by the misspecification of the semi variance in these area. As seen in subsets of spatial errors, low-lying terrain was over exaggerated by the interpolation process especially when using the third order trend. The area in Figure 4c shows peculiar linear artifacts with a NW-SE orientation; evident in all the error surfaces, regardless of the trend order specified; these were a product of the kriging interpolation.

The ridge shown in Figure 4d has a peculiar distribution of errors as the south slope shows positive errors while the north slope has negative errors. This transition of errors over the ridgeline resulted from the difference in horizontal positioning between the 1:10,000 and $1: 50,000$ contours representing a specific line of elevations. Although a 1:10,000 and 1:50,000 contour line depicts the same elevation value, they are displaced horizontally from each other. The displacement was transferred to the DEMs and was evident in error surface. In a general, positive errors were found on the south slope of topographic highs and negative errors on the north slope denoting this shifting phenomenon.

While the spatial distributions of errors provide better insight to the nature of the DEMs errors than the global statistics, visualization of three-dimensional profiles can reveal systematic shifting between the 1:10,000 and 1:50,000 DEMs. All profiles shown in Figure 5 looked similar, regardless of interpolation parameters, in depicting the difference between the DEMs of the two different scales. Although no systematic shifting or stepped artifacts from the interpolation process were apparent between the DEMs, the profiles reinforced that the $1: 50,000$ DEMs do not define well the valleys and local topography as do the 1:10,000 DEMs (Figure 5a, 5b, and 5c) due to a smaller contour interval. The 1:50,000 DEMs flattened the terrain and did not model the microstructure of the local topography as did the 1:10,000 DEMs. Evidenced by the sub images in Figure 5, the 1:10,000 DEMs may model too well large-scale variations in the terrain. None of the blunder errors were apparent in the error surfaces or visible in the profiles.

Geografia (Londrina) v. 26. nº. 2. p. 5 - 22, jul/dez, 2017. 
Figure 4. Spatial distribution of elevation errors for the UK3 1:50,000 DEM.
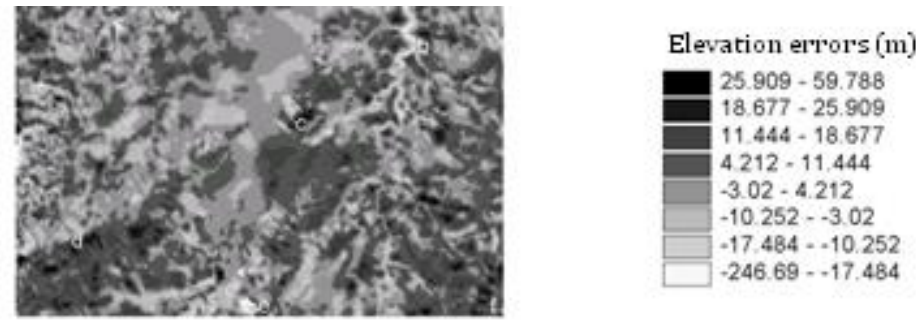

(a)
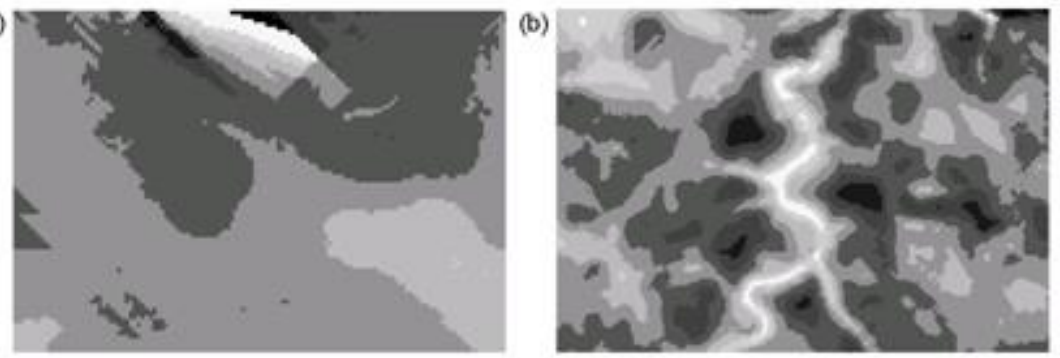

(c)

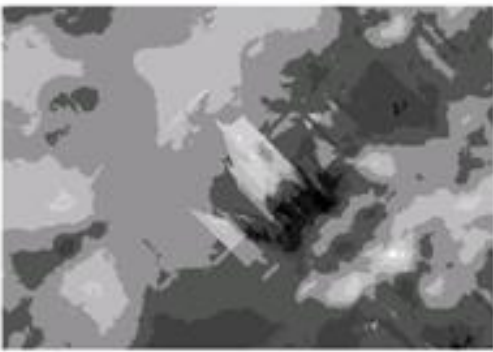

(d)

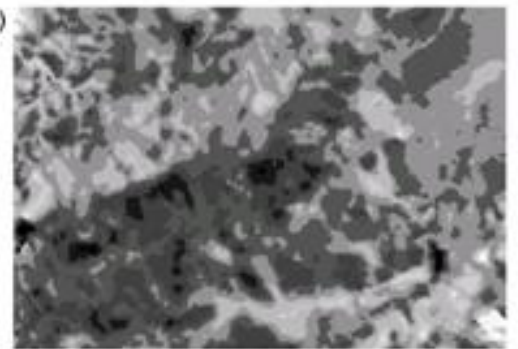

(e)
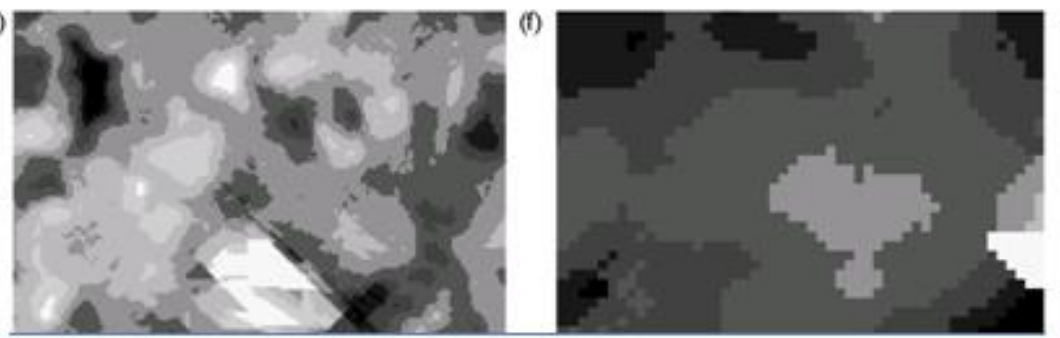

Source: authors.

(a) UK1

(b) UK1

\section{Discussion and Conclusions}

We propose a suite of elevation accuracy assessment techniques with a primary focus of following FGDC geospatial accuracy standards for RMSE calculation. Descriptive statistics, and elevation profiles compared among DEMs of different scales can provide a quantitative and qualitative assessment of error.

Geografia (Londrina) v. 26. n. 2. p. 5 - 22, jul/dez, 2017. 
Global descriptive statistics of minimum and maximum elevation provide an overall assessment only of the error found in the DEMs. Desmet (1997) used global descriptive statistics to quantify elevation errors, but do not indicate their appropriateness as error assessment tools. Jaakkola and Oksanen (2000) rely only on descriptive statistics for their analysis. In this study, they are useful to determine the credibility of the range of elevation values in the resulting DEMs but do not indicate the spatial location and topographic position of unrealistically low or high elevation values distributed across the landscape. Global descriptive statistics can be used as an initial assessment of whether the DEM represents the topography of the area realistically and if some areas contain unrealistic elevation values resulting from extrapolation beyond the range of the original input data.

Figure 5. N-S and E-W elevation profiles across 1:10,000 and 1:50,000 DEMs

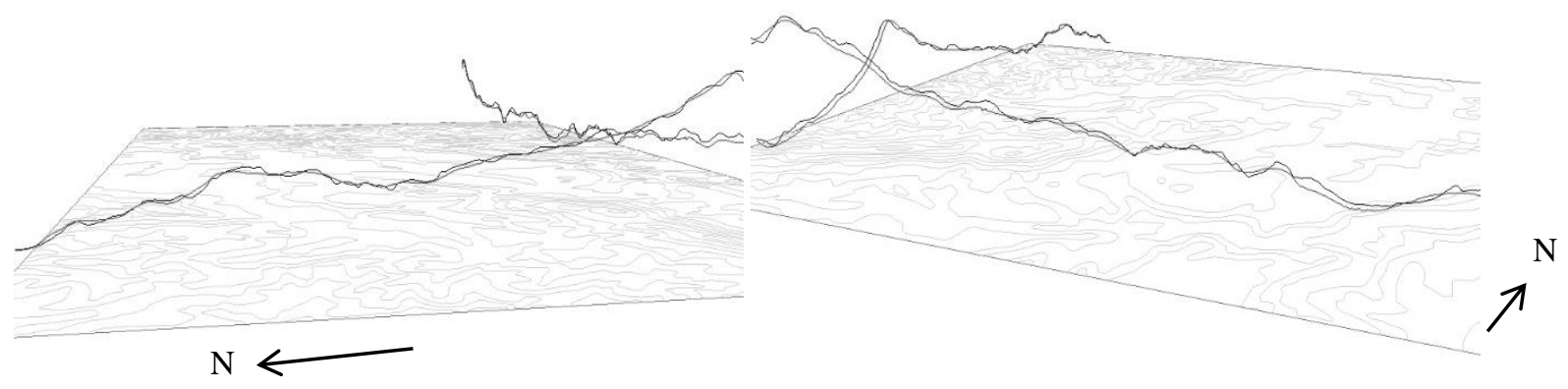

(c) UK1

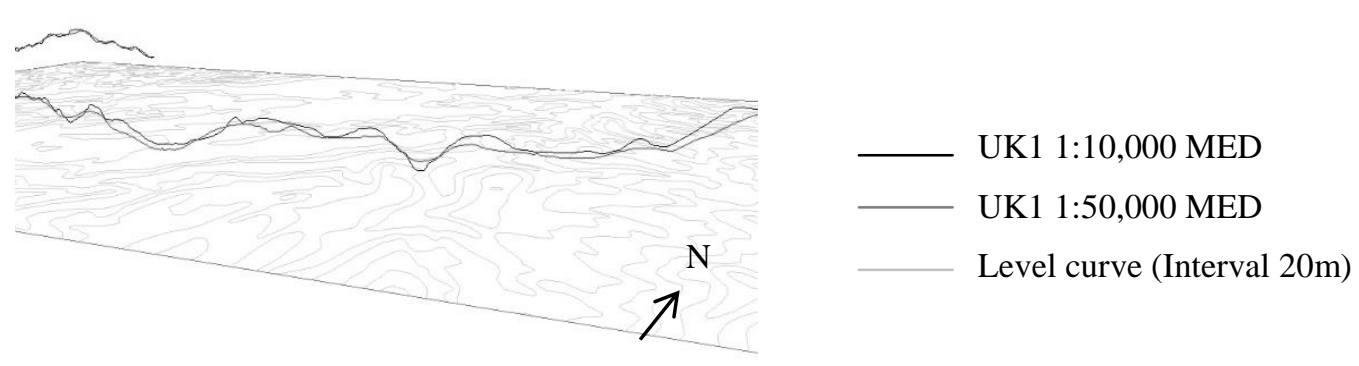

Source: author.

The use of checkpoints as tests of elevation accuracy is not new (BOLSTAD AND STOWE, 1994; LI, 1994; GAO, 1995; DESMET, 1997; GAO, 1997; KYRIAKIDIS ET AL., 1999; GONG ET AL., 2000; WISE, 2000; PRIMA AND YOKOYAMA, 2002; WECHSLER, 2007; WILSON, 2012). Root mean square error (RMSE) usually is calculated from well-defined elevation checkpoints of higher accuracy that are easily identifiable and recoverable both on the ground and in digital mediums used in the accuracy investigation (FEDERAL GEOGRAPHIC 
DATA COMMITTEE, 1998). Contrastingly, our study shows that DEMs interpolated from higher accuracy contours can be used to assess vertical error of DEMs interpolated from contours of smaller scale. Since contours do not qualify as well defined points (FEDERAL GEOGRAPHIC DATA COMMITTEE, 1998), the 1:10,000 scale DEMs must be created using the same interpolation method and parameters as the 1:50,000 scale DEMs. All other interpolation parameters are held constant between the 1:10,000 and 1:50,000 DEMs except for the scale of the source contours. The computed RMSE provides a reliable measure of elevation error in the 1:50,000 DEMs.

One drawback is the use of RMSE as a global measure of accuracy does not spatially locate the errors or indicate the type of error (blunder, random, or systematic), and the number of check points often is small compared to the number of grid cells in the DEMs (WISE, 2000). High RMSE value may result from the interpolation algorithm used, subject to interpolation errors (GAO, 1997) and since the 1:10,000 DEMs were created with an interpolation method, they too are subject to error.

The assumption that the errors are randomly distributed (i.e. no spatial clustering or other pattern among errors), with a mean value of zero and follow a normal distribution is not always upheld or investigated (DESEMET,1997). Without testing the error terms follow a normal distribution the linear vertical accuracy cannot be calculated and the accuracy statement cannot be stated with definitive statistical significance and confidence, leading to a biased conclusion of accuracy. Although acknowledged as a poor indicator of DEM error, RMSE is still widely used. Gao (1997) and Li (1994) do not comment on the appropriateness of RMSE as a DEM error evaluator. Other studies have extended the use of RMSE beyond a general evaluation of accuracy. Lopéz (2002) used RMSE to identify the presence of error outliers for his methods employed and not as a DEM overall accuracy evaluator. Furthermore, if RMSE performs poorly as a global error measure, it could be evaluated spatially with respect to the distribution of elevations. Wechsler (2007) used a relative RMSE that standardizes the RMSE for each grid cell value; since each cell is assigned an RMSE, provides a better spatial distribution of error.

The maps of spatially distributed elevation errors provide a better assessment of the artifacts resulting from the interpolation process and visualize the generalization topographic features like ridges, hilltops, and stream valley bottoms from the 1:50,000 DEMs. Following observations from Prima and Yokoyama (2002), the 1:10,000 DEMs detect inflected contours whereas 1:50,000 DEMs do not; that is, positive elevation differences occur in ravines where contour lines are inflected. Florinsky (1998a) and Wise (2000) recommend assessing DEM accuracy from patterns of error values. Wood and Fisher (1993) noted DEM visualizations and

Geografia (Londrina) v. 26. nº. 2. p. 5 - 22, jul/dez, 2017. 
their derivatives provided good accuracy measure due to flexibility and ease of presentation of uncertainty information. Contrastingly, Kenward et al. (2000) provided images of elevation differences between DEMs tested but offers no explanation of usefulness in assessment of error. The accuracy and plausibility of interpolated prediction locations not represented by the original elevation data is critical since error residuals are smaller along contour lines (i.e. terrain with less variation in elevation is more accurately represented) (GAO, 1997).

The three-dimensional terrain profiles support the observation that $1: 50,000$ DEMs do not represent well the smaller topographic features as do the 1:10,000 DEMs. The profiles are useful for determining systematic shifts between the 1:10,000 and 1:50,000 DEMs although none were detected. These profiles coupled with the spatial distribution of errors indicate the nature and possibly the origin of errors resulting from the interpolation process and their effect on terrain representation. Desmet (1997) used profiles to identify stepped topography caused by a nearest neighbor interpolator that follows original contour lines. Although no stepped topography is apparent in the terrain profiles created here, the highly variable surface of the 1:10,000 DEMs follow the original contours too closely. Hence "ghosts" of the original contours are preserved in the interpolated DEMs, an artifact of the kriging interpolation process. Despite these shortcomings, terrain profiles offer additional visual techniques for error detection.

The DEMs interpolated from the 1:10,000 contours suffer from error due to interpolation parameter choice and possible by the use of kriging. Some of the areas reported in error for the 1:50,000 DEMs may owe to interpolation errors inherent in the 1:10,000 DEMs especially in flat areas where contours are further spaced, possibly influencing the semivariance values. Other studies have used kriging to interpolate DEMs but Thompson et al. (2001) did not report on the errors caused by the choice of interpolator. Desmet (1997) found that kriging caused random artifacts and irregularities propagated into the derivative of terrain attributes such as slope and aspect, and, finally, kriging performed poorly contradictory to the literature. Gao (1997) noted the reported errors may result from the selection of kriging algorithm and suggests modified variogram parameters could yield better DEM accuracy. Hengl et al. (2010) question how to generate DEMs using kriging when the spatial autocorrelation structure with large amounts of local heterogeneity. A possible direction for future work with kriging of elevation DEMs would be to use other interpolators (spline and polynomial trend surfaces) and kriging without a global trend specified.

The accuracy standards of an RMSE computation and subsequently a linear vertical accuracy, Accuracyz, proposed by the FGDC were applied using DEMs interpolated from contour of higher vertical accuracy. Although no well-defined elevation check points existed to

Geografia (Londrina) v. 26. nº. 2. p. 5 - 22, jul/dez, 2017. 
evaluate the vertical accuracy of the $1: 50,000$ DEMs, the $1: 10,000$ DEMs provide a suitable higher accuracy test data source. However, since the 1:10,000 DEMs were interpolated from contours, they are subject to the error inherent in the contours and those resulting from the interpolation process. The contours do not have well defined horizontal positioning as do elevation checkpoints collected using GPS or field survey by theodolite. A good spatially explicit representation of elevation errors is provided though by using the $1: 10,000$ DEMs as the higher accuracy dataset. Attention must be given to the errors present in the 1:10,000 DEMs and they must not be labeled completely error-free.

\section{REFERENCES}

BOLSTAD, P. V. GIS Fundamentals: A first text on geographic information systems. White Bear Lake: Eider Press, 2002.

BOLSTAD, P. V.;STOWE, T. An evaluation of DEM accuracy: elevation, slope, and aspect. Photogrammetric Engineering and Remote Sensing, Bethesda, v. 60, n.11, p.1.327-1.332, 1994.

CARTER, J. R. Digital representations of topographic surfaces. Photogrammetric Engineering and Remote Sensing, Bethesda, n. 54, p.1.577-1.580, 1988.

CHANG, K. T. Introduction to geographic information systems. Boston, MA: McGraw-Hill, 2002.

DESMET, P. J. J. Effects of interpolation errors on the analysis of DEMs. Earth Surface Processes and Landforms, London, n. 22, p.563-580, 1997.

FEDERAL GEOGRAPHIC DATA COMMITTEE. Part 3. National Standard for Spatial Data Accuracy, Geospatial Positioning Accuracy Standards. FGDC-STD-007.3-1998: Washington, D.C., Federal Geographic Data Committee, 1998.

FISHER, P. F.; TATE, N. J. Causes and consequences of error in digital elevation models. Progress in Physical Geography, London, v. 30, n. 4, p.467-489, 2006.

FLORINSKY, I. V. Accuracy of local topographic variables derived from digital elevation models. International Journal of Geographical Information Science, Sidney, v. 12, n. 1, p.47-61, 1998a.

FLORINSKY, I. V. Combined analysis of digital terrain models and remotely sensed data in landscape investigations. Progress in Physical Geography, London, v.22. n.1, p.33-60, 1998b.

GAO, J. Comparison of sampling schemes in constructing DTMs from topographic maps. ITC Journal, Enschede, p. 18-22, 1995.

GAO, J. Resolution and accuracy of terrain representation by grid DEMs at micro-scale. International Journal of Geographical Information Science, Sidney, v. 112, p 199-212, 2007.

GONG, J.; LI, Z.; ZHU, Q.; SUI, H.; ZHOU, Y. Effects of various factors on the accuracy of DEMs: an intensive experimental investigation. Photogrammetric Engineering and Remote Sensing, Bethesda, v. 66, n. 9, p. 1113-1117, 2000.

Geografia (Londrina) v. 26. nº. 2. p. 5-22, jul/dez, 2017. 
HENGL, T.; HEUVELINK, G. B. M; VAN LOON, E. E. On the uncertainty of stream networks derived from elevation data: the error propagation approach. Hydrology and Earth System Sciences, Karlsruhe, v. 14, p. 1153-1165, 2010.

HOLMES, K. W.; CHADWICK, O. A.; AND KYRIAKIDIS, P. C. Error in a USGS 30-meter digital elevation model and its impact on terrain modeling. Journal of Hydrology, v. 233, p. 154-173, 2000.

INSTITUTO GEOGRÁFICO NACIONAL. 1:10,000 Costa Rica topographic map. San Ramón sheet $3346 \mathrm{III}-11.1^{\text {st }}$ Edition. 1991.

INSTITUTO GEOGRÁFICO NACIONAL. 1:50, 000 Costa Rica topographic map. Naranjo sheet 3346III. 2012.

JAAKKOLA, O. A.; OKSANEN, J. Interpolation techniques which save terrain morphology; creating DEMs from contour lines. Geometrics Info Magazine, v. 14, n. 9, p46-49, 2000.

JOHNSTON, K.; VER HOEF, J. M.; KRIVORUCHKO, K.; AND LUCAS, N. Using ArcGIS Geostatistical Analyst. Redlands: Environmental Systems Research Institute Publications, 2004.

KENWARD, T.; LETTENMAIER, D. P.; WOOD, E. F.; FIELDING, E. Effects of digital elevation model accuracy on hydrologic predictions. Remote Sensing of the Environment, v. 74, p. 432444, 2000.

KYRIAKIDIS, P. C.; SHORTRIDGE, A. M.; AND GOODCHILD, M. F. Geostatistics for conflation and accuracy assessment of digital elevtion models. International Journal of Geographical Information Science, Sidney, v. 13, n. 7, p. 677-707, 1999.

$\mathrm{LI}, \mathrm{Z}$. A comparative study of the accuracy of digital terrain models (DTMs) based on various dat models. ISPRS Journal of Photogrammetric and Remote Sensing, Bethesda, v. 49, n. 1, p. 2-11.

LO, C. P.; YEUNG, A. K. W. Concepts and techniques of geographic information systems. Upper Saddle River, NJ: Prentice-Hall, 2002.

LÓPEZ, C. An experiment on the accuracy improvement of photogrammetrically derived DEM. International Journal of Geographical Information Science, v. 16, n. 4, p. 361-375, 2002.

McBRANTEY, A.B.; and WEBSTER, R., 1986. Choosing Functions for Semi-variograms of Soil Properties and Fitting Them to Sampling Estimates. Journal of Soil Science, London, v. 37, p. 617-639. 1986.

MOORE, I. D.; GRAYSON, R. B., LADSON, A. R. Digital terrain modeling: a review of hydrological, geomorphological, and biological applications. Hydrological Processes, Aberdeen, v. 5, p. 3-30, 1991.

NYQUIST, $H$. Certain topics in telegraph transmission theory. Transactions of AIEE, Philadelphia, v. 47, n. 4, p. 617-644, 1928.

PRIMA, O. D. A.; YOKOYAMA, R. DEM generation method from contour lines based on the steepest slope segment chain and a monotone interpolation function. ISPRS Journal of Photogrammetry and Remote Sensing, Bethesda, v. 57, n. 1, p. 86-101, 2002.

ROBINSON, G. J. The accuracy of digital elevation models derived from digitized contour data. Photgrammetric Record, v. 14, n. 83, p. 805-814, 1994.

Geografia (Londrina) v. 26. nº. 2. p. 5 - 22, jul/dez, 2017. 
THOMPSON, J. A.; BELL, J. C.; BUTLER, C. A. Digital elevation model resolution: effects on terrain attribute calculation and quantitative soil-landscape modeling. Geoderma, v. 100, p. 6789, 2000.

WECHSLER, S. P. Uncertainties associated with digital elevation models for hydrologic applications: a review. Hydrology and Earth System Sciences, Karlsruhe, v. 11, n. 4, p. 1.481-1.500, 2007.

WILSON, J. P. Digital terrain modeling. Geomorphology, v. 137, n. 1, p. 107-121, 2012

WISE, S. M. Assessing the quality for hydrological applications of digital elevation models derived from contours. Hydrological Processes, v. 14, p. 1909-1929, 2000.

WOOD, J. D.; FISHER, P. F. Assessing the interpolation accuracy in elevation models. IEEE Computer Graphics and Applications, v. 13, n. 2, p. 48-56, 1993.

${ }^{1}$ Departamento de Ciencias Sociales - Universidad de Costa Rica, Sede de Occidente - San Ramón, Alajuela, Costa Rica

2 Land Use and Environmental Change Institute - University of Florida, Turlington Hall, Gainesville, Florida 32611-7315, USA 